\title{
Water balance and acute mountain sickness before and after arrival at high altitude of $4,350 \mathrm{~m}$.
}

Citation for published version (APA):

Westerterp, K. R., Robach, P., Wouters, J. L. J., \& Richalet, J. P. (1996). Water balance and acute mountain sickness before and after arrival at high altitude of 4,350 m. Journal of Applied Physiology, 80, 1968-1972. https://doi.org/10.1152/jappl.1996.80.6.1968

Document status and date:

Published: 01/01/1996

DOI:

10.1152/jappl.1996.80.6.1968

Document Version:

Publisher's PDF, also known as Version of record

Document license:

Taverne

Please check the document version of this publication:

- A submitted manuscript is the version of the article upon submission and before peer-review. There can be important differences between the submitted version and the official published version of record.

People interested in the research are advised to contact the author for the final version of the publication, or visit the DOI to the publisher's website.

- The final author version and the galley proof are versions of the publication after peer review.

- The final published version features the final layout of the paper including the volume, issue and page numbers.

Link to publication

\footnotetext{
General rights rights.

- You may freely distribute the URL identifying the publication in the public portal. please follow below link for the End User Agreement:

www.umlib.nl/taverne-license

Take down policy

If you believe that this document breaches copyright please contact us at:

repository@maastrichtuniversity.nl

providing details and we will investigate your claim.
}

Copyright and moral rights for the publications made accessible in the public portal are retained by the authors and/or other copyright owners and it is a condition of accessing publications that users recognise and abide by the legal requirements associated with these

- Users may download and print one copy of any publication from the public portal for the purpose of private study or research.

- You may not further distribute the material or use it for any profit-making activity or commercial gain

If the publication is distributed under the terms of Article $25 \mathrm{fa}$ of the Dutch Copyright Act, indicated by the "Taverne" license above, 


\title{
Water balance and acute mountain sickness before and after arrival at high altitude of $4,350 \mathrm{~m}$
}

\author{
KLAAS R. WESTERTERP, PAUL ROBACH, LOEK WOUTERS, AND JEAN-PAUL RICHALET \\ Department of Human Biology, University of Limburg, 6200 MD Maastricht, The Netherlands; and \\ Association pour la Recherche en Physiologie de l'Environnement, F-93012 Bobigny cedex, France
}

\begin{abstract}
Westerterp, Klaas R., Paul Robach, Loek Wouters, and Jean-Paul Richalet. Water balance and acute mountain sickness before and after arrival at high altitude of 4,350 m. J. Appl. Physiol. 80(6): 1968-1972, 1996.--The present study is a first attempt to measure water balance and its components at altitude by using labeled water and bromide dilution and relating the results with acute mountain sickness (AMS). Water intake, total water output, and water output in urine and feces were measured over a 4-day interval before and a subsequent 4-day interval after transport to 4,350 m. Total body water and extracellular water were measured at the start and at the end of the two intervals. There was a close relationship between energy intake and water intake, and the relationship was unchanged by the altitude intervention. Subjects developing AMS reduced energy intake and water intake cor respondingly. The increase in total body water (TBW) in sub jects developing AMS was accompanied by a reduction in total water loss. They did not show the increased urine output, compensating for the reduced evaporative water loss at altitude. Subjects showed a significant increase in TBW after 4 days at altitude. Subjects with AMS showed the biggest shifts in extracellular water relative to TBW. In conclusion, fluid retention in relation to AMS is independent of a change in water requirements due to altitude exposure. Subjects developing AMS were those showing a fluid shift of at least 1 liter from the intracellular to the extracellular compartment or from the extracellular to the intracellular compartment.
\end{abstract}

water intake; water loss; total body water; extracellular water

ONE OF THE PROBLEMS OF HIGH ALTITUDE is the maintenance of water balance. Water availability is low when the only water source is from melting snow. Theoretically, water requirement is increased due to increased insensible water loss at low ambient water vapor pressure (4), but real evidence is lacking. Hoyt et al. (10), measuring energy balance at 2,500-3,100 m during strenuous winter exercise, suggested that the increase in insensible water loss due to decreased barometric pressure would tend to be counterbalanced by additional cold-weather clothing, reducing cutaneous water efflux. The latter suggestion was supported by measurements of total water turnover in subjects climbing Mt. Everest (8,872 m) (18) and during a sojourn on the summit of Mt. Sajama $(6,542 \mathrm{~m})(19)$.

There are few studies on water balance at high altitude. Krzywicki et al. (11) observed hypohydration during a 6-day abrupt exposure to $4,300 \mathrm{~m}$. They suggested that body water loss may be an adaptive mechanism. Subjects showing a relative diuresis in the first days of altitude exposure showed a great reduction in acute mountain sickness (AMS). AMS is known to occur in those who retain fluid (7). On the other hand, Consolazio et al. (3) measured consistently negative fluid balances during 28-day high-altitude exposure to
$4,300 \mathrm{~m}$. One of the speculative explanations was an increase in respiratory water loss due to the increased pulmonary ventilation and the decreased humidity at high altitude. However, there are insufficient data to support this statement.

The present study allowed the measurement of insensible water loss at high altitude by simultaneously measuring total water turnover and fluid loss in urine and feces. Water intake, total water output, and water output in urine and feces were measured over a 4-day interval before and a subsequent 4-day interval after transport to $4,350 \mathrm{~m}$. Total body water (TBW) and extracellular water (ECW) were measured at the start and at the end of the two intervals.

\section{METHODS}

Subjects were three women and seven men aged $30 \pm 8$ (SD) yr, with a body mass index of $21.1 \pm 2.0 \mathrm{~kg} / \mathrm{m}^{2}$ (Table 1 ). They gave their informed consent to participate in the study, and the protocol was approved by the Ethical Committee of Necker Hospital, Paris. The observation started with baseline measurements over 4 days at sea level (Paris, France). On the fifth day, subjects were transported by car and helicopter to a field laboratory on Mont Blanc in the French Alps (Observatoire Vallot, 4,350 m) to be observed for another 4 days (days 6-9; Fig. 1 ). The activity level of the subjects was low. They spent most of the time in reading and household activities and underwent two short exercise tests at sea level and at altitude. Mean ambient temperature, pressure, and relative humidity in the laboratory in Paris and in Observatoire Vallot on Mont Blanc were, respectively, $31 \pm 3$ and $21 \pm$ $3^{\circ} \mathrm{C}, 761 \pm 6$ and $452 \pm 1 \mathrm{mmHg}$, and $58 \pm 4$ and $48 \pm 2 \%$. Measurements of water balance were composed of food and water intake, water loss, and changes in body composition over the two observation intervals.

Food and water intake were measured with a dietary record. Subjects recorded thcir food and fluid intake in a diary, including brand names and cooking recipes where appropriate. Food items were weighed with a table scale in most cases, and volumes were measured with a graduated container. During the stay in the field laboratory, the diaries were examined with the subject present to clarify and eliminate inconsistencies. The energy and water content of the intake were then derived from food tables (14).

Total water loss was measured with labeled water $\left({ }^{2} \mathrm{H}_{2} \mathrm{O}\right)$. The observation covered two 4-day intervals, days 1-4 at sea level and days 6-9 at altitude. Subjects were given a weighed dose of $75 \mathrm{ml}$ of water with a measured enrichment of 4.36276 atom percentage excess ${ }^{2} \mathrm{H}$ so that baseline levels were increased to $-100 \mathrm{parts} / \mathrm{million}(\mathrm{ppm})$. Urine samples for isotope measurement were collected before dosing at night and from the second voiding every morning afterward until the end of the observation interval. Isotope abundancies in the urine samples were measured with an isotope-ratio mass spectrometer (VG Isogas, Aqua Sira). Water loss was calculated from ${ }^{2} \mathrm{H}$ elimination with the equation of Fjeld et al. (5), 
Table 1. Subject characteristics

\begin{tabular}{cccccc}
\hline \hline Subject No. & Sex & Age, yr & Height, $\mathrm{m}$ & Body Weight, kg & Body Fat, \% \\
\hline 1 & M & 29 & 1.80 & 70.0 & 12 \\
2 & M & 30 & 1.82 & 67.5 & 12 \\
3 & M & 26 & 1.92 & 84.0 & 11 \\
4 & F & 26 & 1.61 & 52.2 & 17 \\
5 & F & 34 & 1.63 & 62.5 & 20 \\
6 & F & 22 & 1.56 & 41.5 & 12 \\
7 & M & 23 & 1.76 & 58.0 & 9 \\
8 & M & 24 & 1.78 & 73.0 & 5 \\
9 & M & 36 & 1.82 & 72.0 & 14 \\
10 & M & 47 & 1.66 & 59.4 & 11 \\
Mean \pm SD & & $30 \pm 8$ & $1.74 \pm 0.11$ & $64.0 \pm 12.0$ & $12 \pm 4$ \\
\hline
\end{tabular}

M, male; F, female.

as described previously (18). Subjects drank lowland water at altitude based on the assumption that background ${ }^{2} \mathrm{H}$ levels do not change, as has been observed before (18).

To determine water loss in urine and feces, subjects collected total urine and total feces for all days. Urine was collected in a calibrated container to measure volume at each voiding and was sampled for isotopic analysis if appropriate. Feces were collected in preweighed bags and weighed, and a sample was collected in an airtight container for the measurement of moisture content by freeze-drying in the laboratory.

Body mass, TBW, and ECW were measured at the start and end of the two 4-day intervals. Body mass was measured after the subject arose and emptied the bladder, on a scale $\pm 0.1 \mathrm{~kg}$ (Seca). TBW was calculated as the ${ }^{2} \mathrm{H}$ dilution space from the ${ }^{2} \mathrm{H}$ enrichment of the second voiding minus the ${ }^{2} \mathrm{H}$ concentration of the sample before dose administration (16). The ${ }^{2} \mathrm{H}$ dilution space was divided by 1.04 to correct for isotope exchange with nonaqueous hydrogen of body solids (13). ECW was determined by $\mathrm{Br}$ dilution. A known amount of $\mathrm{NaBr}(60$ $\mathrm{mg} \mathrm{Br} / \mathrm{l}$ estimated TBW) was mixed with the ${ }^{2} \mathrm{H}_{2} \mathrm{O}$ solution and thus administered simultaneously with the ${ }^{2} \mathrm{H}$ solution. Venous blood samples were obtained at 10:30 P.M., before $\mathrm{Br}$ intake, and at 8:00 A.M. the next morning, within $1 \mathrm{~h}$ before or after the second urine voiding, for the measurement of TBW. $\mathrm{Br}$ concentration was determined in serum ultrafiltrate with high-performance liquid chromatography, and ECW was calculated from corrected $\mathrm{Br}$ space, as described previously (17).

Acclimatization to altitude was evaluated by a standardized scoring system of AMS of four symptoms: headache, digestive signs, fatigue, and insomnia (6). The symptoms were scored on a 3-point scale each, four times a day with 4-h intervals.

\section{RESULTS}

Four subjects, two women and two men, developed AMS after transport to $4,350 \mathrm{~m}$. They had a mean AMS
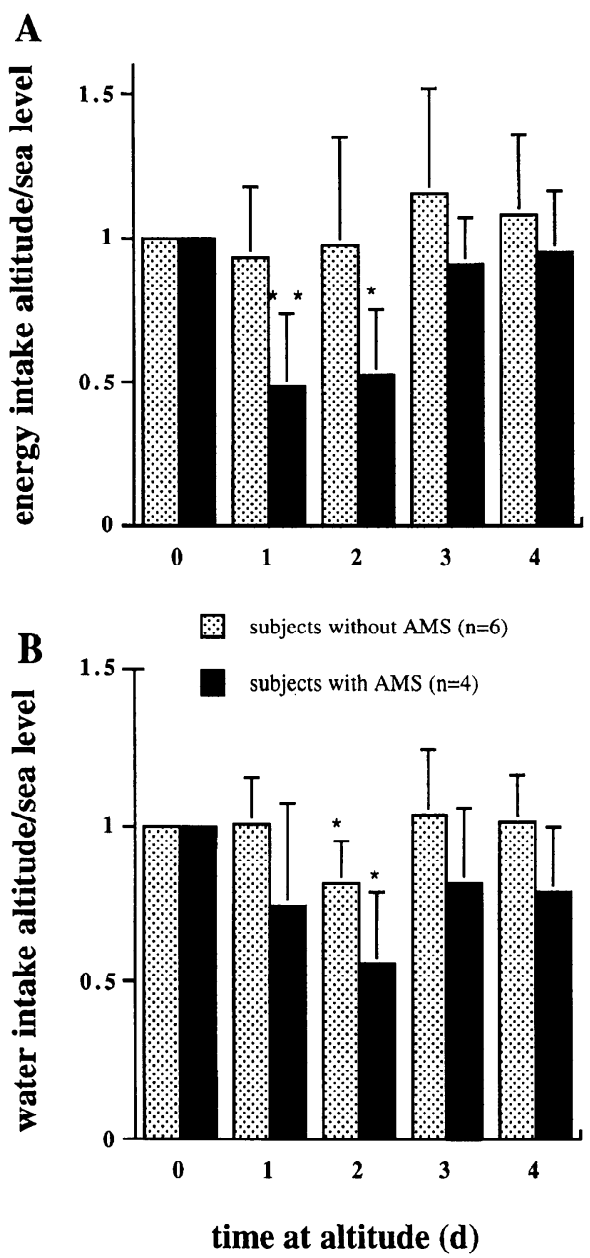

Fig. 2. Energy intake $(A)$ and water intake $(B)$ on days 1-4 after arrival at 4,350 $\mathrm{m}$ expressed as a multiple of 4-day mean value over preceding interval at sea level. Value was significantly different from value over preceding interval at sea level $\left(* P<0.05,{ }^{* *} P<0.01\right)$. AMS, acute mountain sickness.

score, the daily total of four scores, of 17.0 (range 16-18), 14.3 (range 8-19), 5.0 (range 3-7), and 4.5 (range $0-11$ ) on days 1-4 of the 4-day interval at altitude, respectively. The corresponding score for those who did not develop AMS was 2.5 (range 0-9), 2.0 (range 0-7), 0.5 (range $0-1$ ), and 0.5 (range $0-1$ ). Results on food intake and the measured components of water balance are presented separately for the group with AMS $(n=4)$ and the group without AMS $(n=6)$ (Fig. 2).

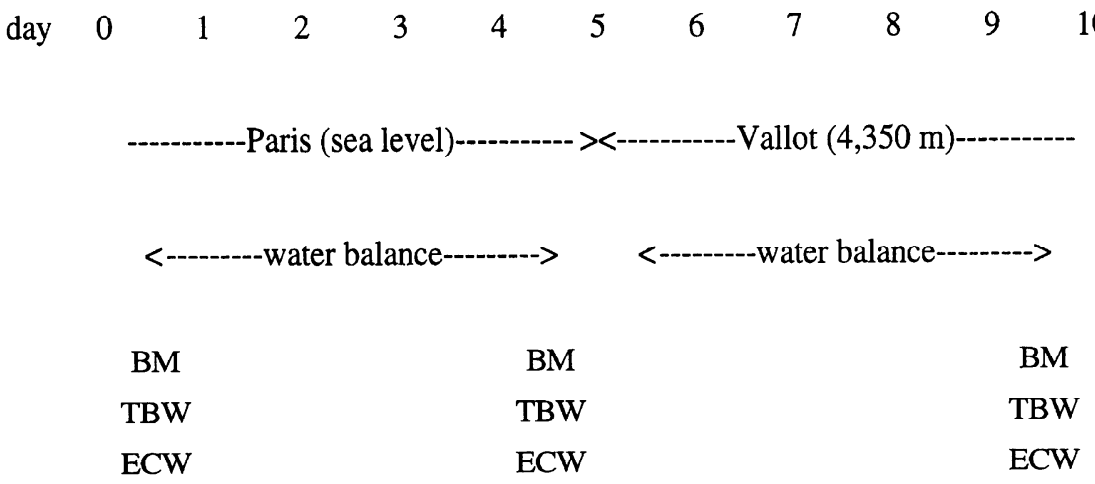

Fig. 1. Protocol. Body mass (BM), total body water (TBW), and extracellular water (ECW) were measured before and after two 4-day observation intervals of water balance, first at sea level (days $1-4)$ and second at 4,350 m (days 6-9). Vallot, Observatoire Vallot, French Alps. 
In a comparison of energy intake of the subsequent days at altitude with the 4-day mean energy intake at sea level, all subjects with AMS showed a reduction of intake at altitude. Energy intake was $48 \pm 25,53 \pm 22$, $91 \pm 16$, and $95 \pm 21 \%$ of the mean sea-level value on the subsequent days at altitude. Corresponding values in the other six subjects were $93 \pm 24,97 \pm 38,115 \pm$ 37 , and $108 \pm 28 \%$. Water intake was more variable but showed the same trend. Water intake in subjects with AMS was $75 \pm 33,56 \pm 23,82 \pm 24$, and $79 \pm 21 \%$ of the mean sea-level value on the subsequent days at altitude. Corresponding values in the other six subjects were $100 \pm 15,81 \pm 14,104 \pm 20$, and $101 \pm 15 \%$. In a comparison of mean energy intake and mean water intake over the two 4-day intervals, there was a significant relationship at sea level $(r=0.83, P<0.01)$ and at altitude $(r=0.84, P<0.01$ ), with no difference between slope and intercept of the two regression lines (analysis of covariance).

Table 2 gives the data on the ${ }^{2} \mathrm{H}$ dilution space and fractional elimination rate from body water of excess ${ }^{2} \mathrm{H}$. Mean total water loss at altitude in subjects with AMS (subjects 3-5 and 10) was significantly reduced to $74 \pm 21 \%$ of the sea-level value $(P=0.05)$, whereas the change in subjects without AMS to $92 \pm 15 \%$ was not significant. Urine production, as a component of water loss, in subjects with AMS was $83 \pm 27,97 \pm 36,99 \pm$ 34 , and $68 \pm 22 \%$ of the mean sea-level value on the subsequent days at altitude. Corresponding values in the other six subjects were $200 \pm 58,165 \pm 52,179 \pm$ 34 , and $142 \pm 50 \%$, i.e., significantly increased on the first day $(P<0.01)$, second day $(P<0.01)$, and third day $(P<0.001)$ at altitude. Water loss in feces was at altitude decreased in all subjects with AMS. The decrease was due to a decrease of mean fecal mass from $0.25 \pm 0.14 \mathrm{~kg} /$ day at sea level to $0.13 \pm 0.08 \mathrm{~kg} /$ day at altitude and a decrease in mean fecal hydration from $79 \pm 5$ to $68 \pm 11 \%$. Water loss in feces at altitude was unchanged in subjects without AMS. The mean fecal mass was $0.19 \pm 0.06 \mathrm{~kg} /$ day at sea level and $0.19 \pm$ $0.10 \mathrm{~kg} /$ day at altitude, and the corresponding values for mean fecal hydration were $62 \pm 17$ and $67 \pm 18 \%$. Evaporative water loss, calculated as total water loss minus urine water and fecal water, was decreased at

Table 2. ${ }^{2} \mathrm{H}$ dilution space and fractional elimination rate from body water of excess ${ }^{2} \mathrm{H}$

\begin{tabular}{|c|c|c|c|c|}
\hline \multirow{2}{*}{$\begin{array}{c}\text { Subject } \\
\text { No. }\end{array}$} & \multicolumn{2}{|c|}{ Sea Level } & \multicolumn{2}{|c|}{ Altitude } \\
\hline & $\mathrm{N}_{\mathrm{H}}$, liters & $k_{\mathrm{H}} /$ day & $\mathrm{N}_{\mathrm{H}}$, liters & $h_{\mathrm{H}} /$ day \\
\hline 1 & 42.1 & 0.08443 & 42.4 & 0.07271 \\
\hline 2 & 41.5 & 0.09785 & 41.6 & 0.07933 \\
\hline 3 & 52.6 & 0.10059 & 51.8 & 0.08796 \\
\hline 4 & 30.5 & 0.11495 & 31.7 & 0.04830 \\
\hline 5 & 34.6 & 0.15496 & 34.8 & 0.13511 \\
\hline 6 & 24.5 & 0.10343 & 23.3 & 0.11663 \\
\hline 7 & 38.0 & 0.08262 & 37.7 & 0.66470 \\
\hline 8 & 48.8 & 0.06842 & 48.4 & 0.07882 \\
\hline 9 & 43.4 & 0.10612 & 43.5 & 0.08877 \\
\hline 10 & 36.2 & 0.08631 & 35.8 & 0.06789 \\
\hline
\end{tabular}

$\mathrm{N}_{\mathrm{H}},{ }^{2} \mathrm{H}$ dilution space; $k_{\mathrm{H}}$, fractional elimination rate from body water of excess ${ }^{2} \mathrm{H}$.

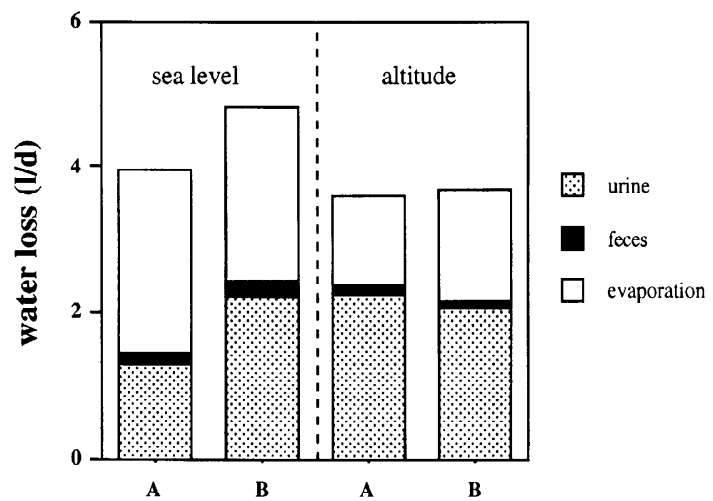

Fig. 3. Water loss and its components in subjects without AMS (A) and subjects with AMS (B) at sea level (left) and at altitude (right).

altitude. In absolute figures, it decreased from $2.5 \pm 0.8$ to $1.3 \pm 0.5 \mathrm{l} / \mathrm{day}(P<0.001)$. Expressed as a proportion of total water loss, it decreased from $57 \pm 14$ to $38 \pm$ $11 \%(P<0.01)$. Changes in evaporative water loss were not different for subjects with AMS and subjects without AMS (Fig. 3).

Mean changes in TBW and ECW were not different for subjects without and with AMS (Fig. 4). There was a significant increase of $1.2 \pm 1.0$ liters between the mean of the two observations at sea level and after 4 days at altitude $(P<0.01)$. The increase in ECW of $0.5 \pm 1.2$ liters was not significant. However, subjects with AMS showed the biggest shifts in ECW relative to TBW. Three subjects gained $>1.5$ liters ECW (subjects 3,4 , and 10) and one subject lost 1.0 liter ECW (subject 5 ), whereas the mean change in ECW in the subjects without AMS was $-0.1 \pm 0.5$ liter (range +0.5 to -0.8 liter).

\section{DISCUSSION}

The present study is a first attempt to measure water balance and its components at altitude by using labeled water and $\mathrm{Br}$ dilution and relating the results with AMS. There was a close relationship between energy intake and water intake, and the relationship was unchanged by the altitude intervention. Subjects developing AMS reduced energy intake and water intake

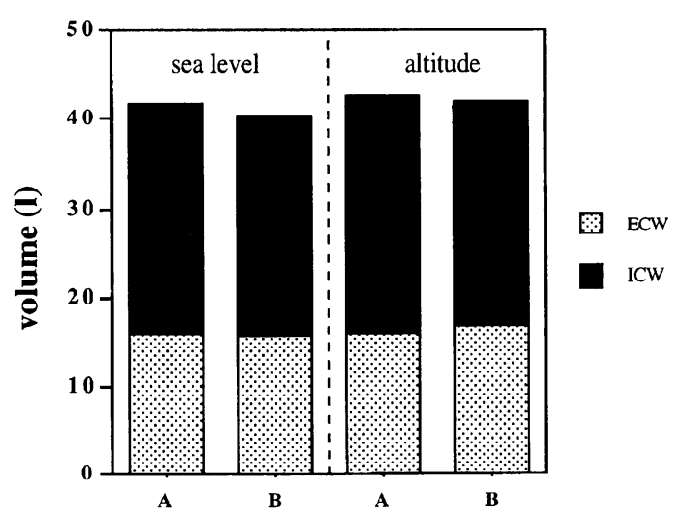

Fig. 4. TBW and its components ECW and intracellular water (ICW) in subjects without AMS (A) and subjects with AMS (B) at sea level (left) and at altitude (right). 
correspondingly because nausea and loss of appetite are part of the clinical syndrome of AMS. The increase in TBW in subjects developing AMS was accompanied by a reduction in total water loss. They did not show the increased urine output, compensating for the reduced evaporative water loss at altitude.

AMS is associated with rapid ascent and with fluid retention (1). The relationship between AMS and fluid retention could be explained in part by a chemoreceptormediated natriuresis and secondary diuresis (9). The ventilatory response to hypoxia (not measured in the present study) depends on the sensitivity of the chemoreceptors and has been shown to be linked both to the susceptibility to AMS (12) and to the altitude-induced diuresis (15). On the other hand, fluid retention seemed to be independent of a change in water requirements due to altitude exposure. The relationship between energy intake and water intake was not affected by the ascent, neither in subjects without AMS nor in subjects with AMS. Apparently, altitude exposure does not affect fluid intake independent of energy (food) intake. Water requirement is not increased. The increase in evaporative water loss due to decreased barometric pressure is counterbalanced by additional clothing reducing cutaneous water efflux, as suggested by Hoyt et al. (10). Evaporative water loss in the present study even decreased from $2.5 \pm 0.8$ to $1.3 \pm 0.5 \mathrm{l} /$ day $(P<0.001)$ or from $57 \pm 14$ to $38 \pm 11 \%(P<0.01)$ of total water loss. The decrease could be an effect of the high temperature during the interval at sea level $\left(31 \pm 3^{\circ} \mathrm{C}\right)$, although temperature at altitude also was relatively high. Subjects stayed nearly all the time in a comfortable hut at room temperatue $\left(21 \pm 3^{\circ} \mathrm{C}\right)$. The difference of $10^{\circ} \mathrm{C}$ between sea level and altitude was probably even less than subjects normally experience in altitude studies. Thus altitude exposure in the presence of sufficient food and water is a problem of how to increase water loss. This study shows for the first time that total water loss was reduced in subjects with AMS because they did not increase diuresis at the reduced evaporative water loss.

Subjects showed a significant increase in TBW after 4 days at altitude. Subjects with AMS showed the biggest shifts in ECW relative to TBW. Hannon et al. (8) observed a shift from ECW to intracellular water (= TBW - ECW), whereas TBW was unchanged in subjects exposed to $4,300 \mathrm{~m}$, under sedentary conditions and no change in environmental temperature $\left(25^{\circ} \mathrm{C}\right)$, in the transport of soldiers from sea level to a laboratory trailer at altitude. Krzywicki et al. (11) observed a decrease in TBW and intracellular water after 6 days exposure to 4,300 $\mathrm{m}$ with "normal" exercise, whereas ECW was increased. In both studies mentioned above, subjects had minimal symptoms of AMS. Whatever happens with TBW at altitude exposure, hypohydration (11), euhydration (8), or hyperhydration (present study), the present study showed that subjects with AMS showed the biggest shifts in ECW relative to TBW. This is in accordance with a study of Carson et al. (2), also showing that maximum severity of AMS accom- panied the greatest fluid shifts. This can be a relative gain (present study, three subjects) or relative loss in ECW (present study, one subject).

In conclusion, fluid retention in relation to AMS is independent of a change in water requirements due to altitude exposure. Subjects developing AMS were those showing a fluid shift of at least 1 liter from the intracellular to the extracellular compartment or from the extracellular to the intracellular compartment.

Address for reprint requests: K. Westerterp, Dept. of Human Biology, Univ. of Limburg, PO Box 616, 6200 MD Maastricht, The Netherlands.

Received 26 June 1995; accepted in final form 23 January 1996.

\section{REFERENCES}

1. Bärtsch, P., N. Pfluger, M. Audétat, S. Shaw, P. Weidemann, P. Vock, W. Vetter, D. Rennie, and O. Oelz. Effects of slow ascent to $4,559 \mathrm{~m}$ on fluid homeostasis. Aviat. Space Environ. Med. 62: 105-110, 1991.

2. Carson, R. P., W. O. Evans, J. L. Shields, and J. P. Hannon. Symptomology, pathophysiology and treatment of acute mountain sickness. Federation Proc. 28: 1085-1091, 1969.

3. Consolazio, C. F., L. O. Matoush, H. L. Johnson, and T. A. Daws. Protein and water balances of young adults during prolonged exposure to high altitude (4,300 meters). Am. J. Clin. Nutr. 21: 154-161, 1968.

4. Ferrus, L., D. Commenges, J. Gire, and P. Varène. Respiratory water loss as a function of ventilatory or environmental factors. Respir. Physiol. 39: 367-381, 1984.

5. Fjeld, C. R., K. H. Brown, and D. A. Schoeller. Validation of deuterium oxide method for measuring average milk intake in infants. Am. J. Clin. Nutr. 48: 671-679, 1988.

6. Hackett, $\mathbf{P}$. The Lake Louise consensus on the definition, and quantification of altitude illness. In: Hypoxia and Mountain Medicine, edited by J. R. Sutton, G. Coates, and C. S. Houston. Burlington, VT: Queen City Printers: 327-330, 1992.

7. Hackett, P. H., D. Rennie, S. E. Hofmeister, R. F. Grover, E. T. Grover, and J. T. Reeves. Fluid retention and relative hypoventilation in acute mountain sickness. Respiration 43: $321-329,1982$

8. Hannon, J. P., K. S. K. Chinn, and J. L. Shields. Effects of acute high-altitude exposure on body fluids. Federation Proc. 28 : 1178-1184, 1969.

9. Honig, A. Peripheral arterial chemoreceptors and reflex control of sodium and water homeostasis. Am. J. Physiol. 257 (Regulatory Integrative Comp. Physiol. 26): R1282-R1302, 1989.

10. Hoyt, R. W., T. E. Jones, C. J. Baker-Fulco, D. A. Schoeller, R. B. Schoene, R. S. Schwartz, E. W. Askew, and A. Cymerman. Doubly labeled water measurement of human energy expenditure during exercise at high altitude. Am. J. Physiol. 266 (Regulatory Integrative Comp. Physiol. 35): R966-R971, 1994.

11. Krzywicki, H. J., C. F. Consolazio, H. L. Johnson, W. C. Nielsen, and R. A. Barnhart. Water metabolism in humans during acute high-altitude exposure $(4,300 \mathrm{~m})$. J. Appl. Physiol. 30: 806-809, 1971.

12. Richalet, J. P., A. Keromes, B. Dersch, F. Corizzi, H. Mehdioui, B. Pophillat, H. Chardonnet, F. Tassery, J. P. Herry, C. Rathat, C. Chaduteau, and B. Darnaud. Caractéristiques physiologiques des alpinistes de haute altitude. Sci. Sports 3: 89-108, 1988.

13. Schoeller, D. A., E. van Santen, D. W. Peterson, W. Dietz, J. Jaspan, and P. D. Klein. Total body water measurements in humans with ${ }^{18} \mathrm{O}$ and ${ }^{2} \mathrm{H}$ labeled water. Am. J. Clin. Nutr. 33: 2686-2693, 1980.

14. Voorlichtingsbureau voor de Voeding. Stichting Nederlands Voedingsstoffenbestand. Dutch Nutrient Data Base 1993. The Hague, The Netherlands: Voorlichtingsbureau voor de Voeding, 1993.

15. Swenson, E. R., T. B. Duncan, S. V. Goldberg, G. Ramirez, S. Ahmad, and R. B. Schoene. Diuretic effect of acute hypoxia in 
humans: relationship to hypoxic ventilatory responsiveness and renal hormones. J. Appl. Physiol. 78: 377-383, 1995.

16. Van Marken Lichtenbelt, W. D, K. R. Westerterp, and L. Wouters. Deuterium dilution as a method to determine total body water: effect of test protocol and sampling time. Br. J. Nutr. 72: 491-497, 1994.

17. Van Marken Lichtenbelt, W. D., K. R. Westerterp, L. Wouters, and S. C. M. Luijendijk. Validation of bioelectrical- impedance measurements as a method to estimate body-water compartments. Am. J. Clin. Nutr. 60: 159-166, 1994.

18. Westerterp, K. R., B. Kayser, F. Brouns, J. P. Herry, and W. H. M. Saris. Energy expenditure climbing Mt. Everest. $J$. Appl. Physiol. 73: 1815-1819, 1992.

19. Westerterp, K. R., B. Kayser, L. Wouters, J.-L. Le Trong, and J.-P. Richalet. Energy balance at high altitude of 6,542 m. J. Appl. Physiol. 77: 862-866, 1994.

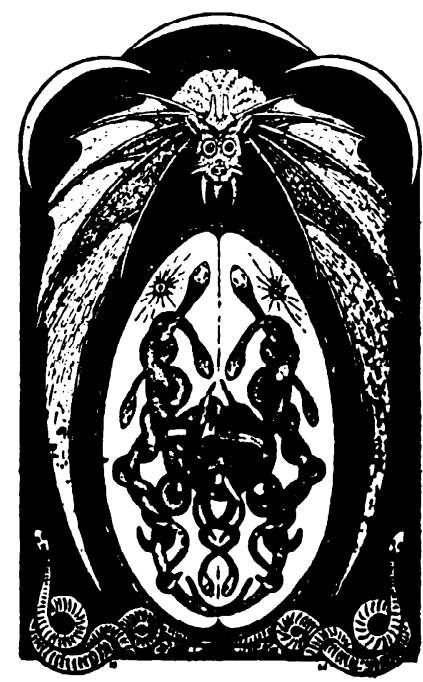

